\title{
Clinical evaluation of Mustababbula churna and Takrarista In the management of Grahani
}

\author{
Research Article
}

\section{Yogita Bisht $^{1 *}$, Rajni Sushma²}

1. PG Scholar, 2. HOD, PG department of Kayachikitsa, Ayurvedic and Unani Tibbia College and Hospital, Karolbagh, New Delhi - 05

\begin{abstract}
Background: The disease in which Grahani or the small intestine gets vitiated and there is impairment of agni (digestive fire) is called Grahani. Anatomically Grahani is said to be situated above the umbilicus and between amashaya (stomach) and pakwashaya (intestines). Physiologically it holds the ingested food for the duration of its digestion before the undigested food residue is propelled into the pakwashaya (intestines). Aim of study: 1) To evaluate the efficacy of Mustababbula churna in the management of Grahani. 2) To evaluate the efficacy the Mustababbula churna and Takrarista in the management of Grahani. Methods: This is a prospective, randomized clinical trial. A total of 80 patients suggestive of features of Grahani roga were enrolled and were randomly divided into two groups- 40 patients each. Group A treated with Mustababbula churna and group B were given Mustababbula churna and Takrarista. The duration of study was 3 months. Results: Both the groups showed statistically significant results in clinical symptoms i.e. altered bowel movements, thirst, anorexia, nausea, blackouts, pain in bones and joints, sour eructations etc but the mean reduction in the symptoms of group B was more than group A. Conclusion: Mustababbula churna is very effective in the management of Grahani but when used with Takrarista it was more effective and also improved the state of agni (digestive fire).
\end{abstract}

Key words: Grahani, Musta, Babbula, Takrarista, Agni, Arista

\section{Introduction:}

When the digestive fire - Agni, which resides in the Grahani, is affected by incorrect lifestyle and eating habits affects the digestive process causing food to be either partially digested or over digested, it leads to the formation of Grahani roga. Ingested food is to be digested, absorbed and assimilated, which is unavoidable for the maintenance of life, and is performed by A gni. (1)

Diarrheal diseases are the most common infectious diseases now-a-days, and are predicted to remain a leading health problem. With contraindications of antimotility agents in infectious diarrhea and an increasing threat of drug resistance, various attempts for developing vaccines against diarrheal pathogens have been made. However, the response to vaccines in developing countries has not been encouraging. In the recent past, attempts have been made to treat infectious diarrhea with supportive therapy such as probiotics; but these are still under development. Therefore, medicinal plants may provide a cost-effective alternative for treatment of such ailments.

*Corresponding Author:

\section{Yogita Bisht}

PG scholar, Department of Kayachikitsa,

Ayurvedic and Unani Tibbia College

Karolbagh, New Delhi - 05

Mobile No.: 09979878245

E-mail: yogitabisht06@yahoo.co.in
The present study was conducted using the ancient ayurvedic literature. Mustababbula churna and Takrarista were used as trial drugs. The present trial drug Mustababbula churna is an anubhoot preparation taken because of its deepan, pachana and sangrahi properties. Takrarista is taken from the standard text Charaka samhita. It contains drugs like panchlavanas, amalaki, haritaki, maricha, yawani, which are herbo mineral in nature and are easily available and the preparation is simple as well as cost effective.(2)

\section{Materials and Methods:}

Study design: It is a prospective, randomized type of clinical trial.

Inclusion criteria:

- Patients between the ages of 16- 65 yrs were included.

- Patients with sign and symptoms of Grahani as explained in classics \& which are devoid of any other complications, which does not disturb in treatment pattern. (3)

\section{Exclusion criteria:}

- Patients suffering from acute diarrhoea, intestinal tuberculosis, ulcerative colitis, crohn's disease, sprue, celiac disease, gastric and peptic ulcer, associated with significant complications like haemorrhage, perforation, strictures, colonic cancer, toxic mega colon etc.

- Patients suffering from ano-rectal diseaseshemorrhoids, fistula and rectal prolapse.

- Patients suffering from systemic disorders like diabetes mellitus, hypertension etc, 
hyperthyroidism and hypothyroidism, pregnancy and lactation, and patients who have taken antibiotics in the last 15 days.

\section{Selection of patients}

A total of 80 patients were randomly selected irrespective of sex, caste, creed, religion, economic status, profession or marital status. The cases were recorded with the help of a special proforma prepared for this purpose. All patients had given informed consent for clinical examination, investigations and drug administration for the purpose of this study.

\section{Grouping of patients:}

Patients were randomly divided into two groups of 40 each.

- Group A: The patients were treated with Mustababbula churna. Out of 40 patients, 35 had completed the course of treatment and 5 patients were discontinued.

- Group B: The patients were treated with Mustababbula churna and Takrarista. In this group, all the patients had completed the course of treatment.

During the period of treatment patients were examined for every 15 days and changes were recorded. The study and observation were clinical in nature. During this period of treatment the patients were advised to follow the pathya ahara viharas (do's and don'ts) as per ayurvedic classics.

\section{Criteria of assessment:}

Assessment was done based on the improvement in signs and symptoms and investigations. The clinical symptomatology was divided into four grades (0-3) and change in these gradations of each symptom was to assess the effect of treatment provided.

\section{Subjective criteria:}

\section{Altered bowel movements}

$\begin{array}{cll}\text { Score } & \text { Grade } & \text { Criteria for grading } \\ 0 & \text { Absent } & \text { Regular bowel } \\ 1 & \text { Mild } & \text { 2 times a week } \\ 2 & \text { Moderate } & \text { 3- } 4 \text { times a week } \\ 3 & \text { Severe } & \text { 5- } 6 \text { times a week }\end{array}$

\section{Increased thirst}

\begin{tabular}{|c|c|c|}
\hline & Absent & Normal thirst \\
\hline & Mild & Satiated after drinking water \\
\hline & Moderate & $\begin{array}{c}\text { Moderately } \\
\text { taking water }\end{array}$ \\
\hline & Severe & $\begin{array}{l}\text { Severely altered, not satiated by } \\
\text { plain water }\end{array}$ \\
\hline
\end{tabular}

\section{Anorexia}

$\begin{array}{lll}0 & \text { Absent } & \text { Normal appetite } \\ 1 & \text { Mild } & \text { Occasional } \\ 2 & \text { Moderate } & \text { Daily at least two times a day } \\ 3 & \text { Severe } & \text { Daily present most of the day }\end{array}$

\begin{tabular}{|c|c|c|}
\hline \multicolumn{3}{|c|}{ Bad taste in mouth } \\
\hline 0 & Absent & No bad taste \\
\hline 1 & Mild & Occasional \\
\hline 2 & Moderate & Frequent \\
\hline 3 & Severe & Troublesome \\
\hline \multicolumn{3}{|c|}{ Nausea } \\
\hline 0 & Absent & No nausea \\
\hline 1 & Mild & Occasional \\
\hline 2 & Moderate & 1- 2 times per day \\
\hline 3 & Severe & More than 2 times per day \\
\hline \multicolumn{3}{|c|}{ Blackouts } \\
\hline 0 & Absent & No blackouts \\
\hline 1 & Mild & Sometimes \\
\hline 2 & Moderate & Often \\
\hline 3 & Severe & Always \\
\hline \multicolumn{3}{|c|}{ Swelling over extremities } \\
\hline 0 & Absent & No swelling \\
\hline 1 & Mild & Noted only on keen observation \\
\hline 2 & Moderate & Observable \\
\hline 3 & Severe & Notable swelling \\
\hline \multicolumn{3}{|c|}{ Pain in bones and joints } \\
\hline 0 & Absent & No pain \\
\hline 1 & Mild & Occasional \\
\hline 2 & Moderate & For some time everyday \\
\hline 3 & Severe & Always/ most of the day \\
\hline \multicolumn{3}{|c|}{ Vomiting } \\
\hline 0 & Absent & No vomiting \\
\hline 1 & Mild & Occasional \\
\hline 2 & Moderate & 1- 2 times per day \\
\hline 3 & Severe & More than 2 times per day \\
\hline \multicolumn{3}{|c|}{ Fever } \\
\hline 0 & Absent & Afebrile \\
\hline 1 & Mild & $98^{\circ} \mathrm{F}-99^{\circ} \mathrm{F}$ \\
\hline 2 & Moderate & $100^{\circ} \mathrm{F}-101^{\circ} \mathrm{F}$ \\
\hline 3 & Severe & $102^{\circ} \mathrm{F}-103^{\circ} \mathrm{F}$ \\
\hline \multicolumn{3}{|c|}{ Sour eructation } \\
\hline 0 & Absent & No sour eructation \\
\hline 1 & Mild & Occasional \\
\hline 2 & Moderate & Frequent/ after meals \\
\hline 3 & Severe & Very much frequent irrespective \\
\hline
\end{tabular}

\section{Associated symptoms Frequency of bowel \\ 0 Absent 1-2 motions per day \\ 1 Mild 3-5 motions per day \\ 2 Moderate 5- 7 motions per day \\ 3 Severe $>7$ motions per day}

Mucous in stool

0 Absent No mucous

1 Mild Often little amount of mucous

2 Moderate Every time mucous with motion

3 Severe Large amount of mucous with every stool

Tenesmus

0 Absent No tenesmus

1 Mild Occasionally mild tenesmus

2 Moderate Tenesmus at every defecation

3 Severe Severe tenesmus at every defecation, interrupting work 
Objective parameters

Abdominal Tenderness

0 Absent No tenderness

1 Mild Subjective experience of tenderness

2 Moderate Wincing of face on pressure

3 Severe Resist touching

Trial drugs:

Ingredients of Mustababbula churna:

\begin{tabular}{|l|l|c|c|}
\hline Drug & Botanical name & $\begin{array}{l}\text { Part } \\
\text { used }\end{array}$ & Quantity \\
\hline Mustak & $\begin{array}{l}\text { Cyperus } \\
\text { rotundus } \text { Linn. }\end{array}$ & Rhizome & 1 part \\
\hline Babbula & $\begin{array}{l}\text { Acacia Arabica } \\
\text { Linn. }\end{array}$ & Bark & 1 part \\
\hline
\end{tabular}

Ingredients of Takrarista:

\begin{tabular}{|l|l|c|c|}
\hline Drug & $\begin{array}{l}\text { Botanical } \\
\text { name }\end{array}$ & $\begin{array}{c}\text { Part } \\
\text { used }\end{array}$ & $\begin{array}{c}\text { Quantit } \\
\mathbf{y}\end{array}$ \\
\hline Yamani & $\begin{array}{l}\text { Tachyspermum } \\
\text { ammi Sprague }\end{array}$ & Fruit & $144 \mathrm{~g}$ \\
\hline Amalaki & $\begin{array}{l}\text { Emblica } \\
\text { officinalis } \\
\text { Gaertn. }\end{array}$ & Pericarp & $144 \mathrm{~g}$ \\
\hline Pathya & $\begin{array}{l}\text { Terminalia } \\
\text { chebula } \text { Retz. }\end{array}$ & Pericarp & $144 \mathrm{~g}$ \\
\hline Maricha & $\begin{array}{l}\text { Piper nigrum } \\
\text { Linn. }\end{array}$ & Fruit & $144 \mathrm{~g}$ \\
\hline $\begin{array}{l}\text { Saindhava } \\
\text { lavana }\end{array}$ & Rock salt & & $48 \mathrm{~g}$ \\
\hline $\begin{array}{l}\text { Sauvarcala } \\
\text { lavana }\end{array}$ & Black salt & & $48 \mathrm{~g}$ \\
\hline $\begin{array}{l}\text { Vida lavana } \\
\text { Ammonium } \\
\text { chloride }\end{array}$ & & $48 \mathrm{~g}$ \\
\hline $\begin{array}{l}\text { Samudra } \\
\text { lavana }\end{array}$ & Sea salt & & $48 \mathrm{~g}$ \\
\hline $\begin{array}{l}\text { Romaka } \\
\text { lavana }\end{array}$ & Sambhar salt & & $48 \mathrm{~g}$ \\
\hline $\begin{array}{l}\text { Takra } \\
\text { (freshly } \\
\text { prepared) }\end{array}$ & Buttermilk & & $3.2 \mathrm{lt}$ \\
\hline
\end{tabular}

\section{Method of preparation of Trial drugs:}

Mustababbula churna: Both the drugs of pharmacopoeial quality were taken in equal amount. They were then washed (first with cold water and then with hot water respectively), dried, and then powdered individually and passed through sieve number 85 . Both ingredients were then mixed together. The churna was then passed through sieve number 44 to obtain a homogenous blend and packed in an air tight container. (4)

Dose: 4- 6 grams orally with luke warm water twice a day after meals. The dose of patients between 16- 50 yrs was 4 grams and for those patients between 50-65 yrs was 6 grams respectively.
Takrarista:

Raw materials of pharmacopoeial quality were taken. Ingredient numbered 1 to 4 of the formulation composition were washed and crushed. Ingredients numbered 5 (panchlavana) of the formulation composition were cleaned, dried and powdered individually and passed through the sieve number 85 to obtain fine powder. All the above contents were mixed in freshly prepared takra. This solution was then strained and kept in the fermentation vessel. The mouth of the vessel was sealed. The container was kept in sunlight for 3 weeks. After 3 weeks, the lid was removed, and the contents examined to ascertain whether the process of fermentation had been completed according to Chakrapani's commentary that "jatamiti amla rasataya jatam". The fluid was first decanted and then strained after two or three days. When the fine suspended particles settled down, it was strained again and bottled. (5)

Dose: $20 \mathrm{ml}$ of Takrarista with equal water orally after meals, two times a day.

\section{Investigations:}

Following investigations were carried out during the trial:

- Complete blood count

- Kidney function test and Liver function test

- Blood glucose- fasting and post prandial

- Urine- routine and microscopic

- Stool examination for consistency, presence of mucous, undigested fibres, harmful bacteria, viruses, occult blood, ova and cysts

- Ultrasonography if needed

\section{Statistical analysis}

The data generated in the clinical study was expressed in terms of mean, standard deviation. Appropriate " $t$ " test was applied to test the significance of comparative mean values of before and after treatment by using statistical software - SPSS 17.0. The significance was assessed at $0.05,0.01$ and 0.001 levels.

Interpretation of results
Result:

Marked relief

Moderate relief

Mild relief

No relief

\section{Criteria for assessment}

75 to $100 \%$ relief in signs and symptoms of Grahani

More than $50 \%$ and less than $75 \%$

More than $25 \%$ and less than $50 \%$

Less than $25 \%$ was taken

\section{Observations and Results:}

The results were analysed on the basis of improvement in clinical features. Improvement in modern parameters of investigation was considered as supporting criteria. The observation of demographic profile revealed that males predominated the study 
accounting for $73.75 \%$ of total number of cases. High incidence was noted among moderately working $(68.75 \%)$, semi-urban $(68.75 \%)$, lower middle class $(55 \%)$, married $(66.25 \%)$, illiterate $(30 \%)$ and tea and coffee consuming group (43.75\%).

People having vata-pitta prakriti were found more prone $(61.25 \%)$ to Grahani. The katu $(43.75 \%)$ and amla $(22.50 \%)$ rasa consuming groups were affected more than rest of the patients. Common presenting symptoms were alternate bowel movements $(100 \%$ in both the groups), anorexia ( $91.42 \%$ in group A and $100 \%$ in group B) and pain in bones and joints (82.85\% in group A and $82.5 \%$ in group B).

In group A, patients have shown highly significant improvement in all symptoms except in chardi (vomiting) and shoon pada kara (swelling in limbs) ( $p>0.05$ ). Moderately significant in vairasya (bad taste in mouth) $(p<0.01)$ and mildly significant in jwara (fever) $(p<0.05)$. In group $\mathrm{B}$, patients have shown significant improvement in all symptoms except in shoon pada kara (swelling in limbs) and chardi (vomiting) $(p>0.05)$. Moderately significant result was seen in jwara (fever) $(p<0.01)$. Between group comparison, group B patients have shown better rate of improvement.

\section{Observations}

Age group

$16-25$

26- 35

$36-45$

$46-55$

$56-65$

Sex

Male

Female

\section{Percentage}

28.75

35

18.75

11.25

6.25

73.75

26.25

\section{Habitat}

Urban

Semi- urban

Rural

Addiction

Tobacco (smoking/chewing) 30

Alcohol

Tea/ coffee

Not present

Deha prakriti

Vata kapha

Pitta kapha

Vata pitta

Dietary habits

Vegetarians

Mixed diet

Agni

Teekshnagni

Vishamagni

Mandagni

Dominant guna in diet

Guru 10

Sheeta

33.75

Ruksha 23.75

Laghu $\quad 8.75$

Snigdha $\quad 15$

Ushna $\quad 8.75$

Dominant rasa in diet

Madhur 10

Amla 22.5

Lavana $\quad 18.75$

Katu $\quad 43.75$

Tikta 5

Kashaya 0

Table 1: Effect of Mustababbula churna (group A) on symptoms of Grahani

\begin{tabular}{|l|l|l|l|l|l|l|l|l|l|}
\hline $\begin{array}{l}\text { Sr. } \\
\text { No }\end{array}$ & Parameter & BT & AT & \% & S.D. & S.E. & t-value & “p” & $\begin{array}{l}\text { Result } \\
\text { (df-34) }\end{array}$ \\
\hline 1 & $\begin{array}{l}\text { Vibadh va drava mala } \\
\text { (alternate bowel movements) }\end{array}$ & 1.54 & 0.48 & 68.83 & 0.48 & 0.08 & 12.99 & $<0.001$ & HS \\
\hline 2 & Trishna (thirst) & 0.62 & 0.14 & 77.41 & 0.61 & 0.10 & 4.69 & $<0.001$ & HS \\
\hline 3 & Arochaka (anorexia) & 1.4 & 0.57 & 59.28 & 0.70 & 0.12 & 6.93 & $<0.001$ & HS \\
\hline 4 & $\begin{array}{l}\text { Vairaisya (bad taste in } \\
\text { mouth) }\end{array}$ & 0.45 & 0.11 & 75.55 & 0.54 & 0.09 & 3.76 & $<0.01$ & $\begin{array}{l}\text { Moderately } \\
\text { S }\end{array}$ \\
\hline 5 & Prasek (nausea) & 0.77 & 0.23 & 70.12 & 0.56 & 0.09 & 5.73 & $<0.001$ & HS \\
\hline 6 & Tamak (blackouts) & 1.2 & 0.69 & 42.5 & 0.51 & 0.08 & 6.00 & $<0.001$ & HS \\
\hline 7 & $\begin{array}{l}\text { Shoon paad kara (swelling } \\
\text { in limbs) }\end{array}$ & 0.08 & 0.06 & 25 & 0.17 & 0.03 & 1.00 & $>0.05$ & IS \\
\hline 8 & $\begin{array}{l}\text { Asthi sandhi ruk (pain in } \\
\text { bones and joints) }\end{array}$ & 1.23 & 0.60 & 51.21 & 0.59 & 0.10 & 6.21 & $<0.001$ & HS \\
\hline 9 & Chardi (vomitting) & 0.14 & 0.08 & 42.85 & 0.23 & 0.03 & 1.43 & $>0.05$ & IS \\
\hline 10 & Jwara (fever) & 0.14 & 0.03 & 78.57 & 0.32 & 0.05 & 2.09 & $<0.05$ & Mildly S \\
\hline 11 & $\begin{array}{l}\text { Tikta amla udgar (sour } \\
\text { eructations) }\end{array}$ & 1.1 & 0.45 & 59.09 & 0.59 & 0.09 & 6.57 & $<0.001$ & HS \\
\hline
\end{tabular}

It was observed that the effect of Mustababbula churna in this study showed highly significant results at $\mathrm{p}<0.001$ in all symptoms except in shoon pada kara and chardi where it showed insignificant result at $\mathrm{p}>$ 0.005 . In Vairasya it showed moderately significant i.e $\mathrm{p}<0.01$ and in Jwara it showed mildly significant result at $\mathrm{p}<0.05$. 
International Journal of Ayurvedic Medicine, 2016, 7(1), 81-87

Table 2: Effect of Mustababbula churna and Takrarista (group B) on symptoms of Grahani

\begin{tabular}{|l|l|l|l|l|l|l|l|l|l|}
\hline $\begin{array}{l}\text { Sr. } \\
\text { No }\end{array}$ & Parameter & BT & AT & $\mathbf{\%}$ & S.D. & S.E. & t-value & “p” & $\begin{array}{l}\text { Result } \\
\text { (df-39) }\end{array}$ \\
\hline 1 & $\begin{array}{l}\text { Vibadh va drava mala } \\
\text { (alternate } \\
\text { movements) }\end{array}$ & 1.37 & 0.25 & 81.75 & 0.61 & 0.95 & 11.72 & $<0.001$ & HS \\
\hline 2 & Trishna (thirst) & 0.90 & 0.15 & 83.33 & 0.74 & 0.11 & 6.38 & $<0.001$ & HS \\
\hline 3 & Arochaka (anorexia) & 0.7 & 0.15 & 78.57 & 0.67 & 0.10 & 5.13 & $<0.001$ & HS \\
\hline 4 & $\begin{array}{l}\text { Vairaisya (bad taste in } \\
\text { mouth) }\end{array}$ & 0.72 & 0.05 & 93.05 & 0.57 & 0.09 & 7.45 & $<0.001$ & HS \\
\hline 5 & Prasek (nausea) & 0.72 & 0.05 & 93.05 & 0.57 & 0.09 & 7.45 & $<0.001$ & HS \\
\hline 6 & Tamak (blackouts) & 1.02 & 0.45 & 55.88 & 0.63 & 0.10 & 5.71 & $<0.001$ & HS \\
\hline 7 & $\begin{array}{l}\text { Shoon paad kara (swelling } \\
\text { in limbs) }\end{array}$ & 0.12 & 0.07 & 41.66 & 0.22 & 0.03 & 1.43 & $>0.05$ & IS \\
\hline 8 & $\begin{array}{l}\text { Asthi sandhi ruk (pain in } \\
\text { bones and joints) }\end{array}$ & 1.12 & 0.43 & 61.60 & 0.68 & 0.11 & 6.44 & $<0.001$ & HS \\
\hline 9 & Chardi (vomiting) & 0.12 & 0.05 & 58.33 & 0.26 & 0.04 & 1.77 & $>0.05$ & IS \\
\hline 10 & Jwara (fever) & 0.2 & 0.05 & 75 & 0.36 & 0.05 & 2.62 & $<0.01$ & Moderately S \\
\hline 11 & $\begin{array}{l}\text { Tikta amla udgar (sour } \\
\text { eructations) }\end{array}$ & 1.07 & 0.35 & 67.28 & 0.64 & 0.10 & 7.16 & $<0.001$ & HS \\
\hline
\end{tabular}

In this study it was observed that the effect of Mustababbula churna and Takrarista showed highly significant results at $p<0.001$ in all symptoms except in shoon pada kara and chardi where it showed insignificant results at $p>0.05$. In Jwara it showed moderately significant result at $p<0.01$.

Table 3: Comparative effect of therapies on subjective parameters in Group A and Group B.

\begin{tabular}{|c|c|c|c|c|c|c|c|c|c|c|c|c|}
\hline \multirow{2}{*}{$\begin{array}{l}\text { Sr. } \\
\text { No }\end{array}$} & \multirow{2}{*}{ Chief complaints } & \multicolumn{2}{|c|}{$\begin{array}{c}\text { No. of } \\
\text { patients }\end{array}$} & \multicolumn{2}{|c|}{ Mean } & \multicolumn{2}{|c|}{ S.D } & \multicolumn{2}{|c|}{ S.E } & \multirow{2}{*}{$\begin{array}{c}\text { t } \\
\text { valu } \\
\text { e }\end{array}$} & \multirow{2}{*}{$\begin{array}{c}\mathbf{P} \\
\text { valu } \\
\mathbf{e}\end{array}$} & \\
\hline & & $\mathbf{A}$ & B & $\mathbf{A}$ & B & $\mathbf{A}$ & B & $\mathbf{A}$ & B & & & \\
\hline 1 & $\begin{array}{l}\text { Vibadh va drava } \\
\text { mala (alternate } \\
\text { bowel movements) }\end{array}$ & 35 & 40 & 0.48 & 0.25 & 0.56 & 0.43 & 0.09 & 0.06 & 2.03 & 0.04 & $\begin{array}{l}\text { Mildl } \\
\text { y S }\end{array}$ \\
\hline 2 & Trishna (thirst) & 18 & 26 & 0.14 & 0.15 & 0.35 & 0.36 & 0.06 & 0.05 & -0.08 & 0.9 & $\overline{\mathrm{IS}}$ \\
\hline 3 & $\begin{array}{l}\text { Arochaka } \\
\text { (anorexia) }\end{array}$ & 32 & 40 & 0.57 & 0.50 & 0.65 & 0.59 & 0.11 & 0.09 & 0.49 & 0.62 & IS \\
\hline 4 & $\begin{array}{l}\text { Vairaisya (bad taste } \\
\text { in mouth) }\end{array}$ & 14 & 19 & 0.11 & 0.15 & 0.32 & 0.42 & 0.05 & 0.06 & -0.40 & 0.68 & IS \\
\hline 5 & Prasek (nausea) & 22 & 25 & 0.02 & 0.05 & 0.16 & 0.22 & 0.02 & 0.03 & -0.47 & 0.64 & IS \\
\hline 6 & Tamak (blackouts) & 28 & 31 & 0.68 & 0.45 & 0.67 & 0.55 & 0.11 & 0.08 & 1.66 & 0.10 & $\overline{\mathrm{IS}}$ \\
\hline 7 & $\begin{array}{l}\text { Shoon paad kara } \\
\text { (swelling in limbs) }\end{array}$ & 02 & 04 & 0.05 & 0.07 & 0.23 & 0.26 & 0.03 & 0.04 & -0.30 & 0.76 & IS \\
\hline 8 & $\begin{array}{l}\text { Asthi sandhi ruk } \\
\text { (pain in bones and } \\
\text { joints) }\end{array}$ & 29 & 33 & 0.60 & 0.42 & 0.65 & 0.50 & 0.11 & 0.07 & 1.31 & 0.19 & $\overline{\text { IS }}$ \\
\hline 9 & Chardi (vomitting) & 04 & 04 & 0.08 & 0.05 & 0.28 & 0.22 & 0.04 & 0.03 & 0.60 & 0.54 & IS \\
\hline 10 & Jwara (fever) & 05 & 07 & 0.02 & 0.05 & 0.16 & 0.22 & 0.02 & 0.03 & -0.46 & 0.64 & IS \\
\hline 11 & $\begin{array}{l}\text { Tikta amla udgar } \\
\text { (Sour eructations) }\end{array}$ & 27 & 31 & 0.45 & 0.35 & 0.65 & 0.53 & 0.11 & 0.08 & 0.77 & 0.43 & $\overline{\mathrm{IS}}$ \\
\hline 12 & Frequency of stool & 35 & 38 & 0.31 & 0.22 & 0.47 & 0.47 & 0.07 & 0.07 & 0.81 & 0.42 & $\overline{\mathrm{IS}}$ \\
\hline 13 & Mucus in stool & 09 & 11 & 0.14 & 0.10 & 0.42 & 0.30 & 0.07 & 0.04 & 0.50 & 0.61 & $\overline{\mathrm{IS}}$ \\
\hline 14 & Tenesmus & 14 & 15 & 0.22 & 0.10 & 0.42 & 0.30 & 0.07 & 0.04 & 1.51 & 0.13 & $\overline{\mathrm{IS}}$ \\
\hline 15 & $\begin{array}{l}\text { Abdominal } \\
\text { tenderness }\end{array}$ & 15 & 18 & 0.20 & 0.20 & 0.40 & 0.40 & 0.06 & 0.06 & 0.00 & 1.00 & IS \\
\hline
\end{tabular}


On comparing the effect of therapies, it was observed that the difference in the results were insignificant at $p>0.05$ in all symptoms except in alternate bowel movement where it was observed to be mildly significant at $p<0.05$.

Table No 4: Comparative effect of therapies on objective parameters in Group A and Group B.

\begin{tabular}{|c|c|c|c|c|c|c|c|c|c|c|c|c|}
\hline \multirow{2}{*}{$\begin{array}{l}\text { Sr. } \\
\text { No }\end{array}$} & \multirow{2}{*}{$\begin{array}{l}\text { Objective } \\
\text { parameter }\end{array}$} & \multicolumn{2}{|c|}{ No. of patients } & \multicolumn{2}{|c|}{ Mean } & \multicolumn{2}{|l|}{ S.D } & \multicolumn{2}{|l|}{ S.E } & \multirow[t]{2}{*}{$\mathbf{T}$} & \multirow[t]{2}{*}{ p } & \\
\hline & & $\mathbf{A}$ & $\overline{\mathbf{B}}$ & $\overline{\mathbf{A}}$ & $\overline{\mathbf{B}}$ & $\bar{A}$ & $\overline{\mathbf{B}}$ & $\overline{\mathbf{A}}$ & $\bar{B}$ & & & \\
\hline 1 & $\mathrm{Hb} \%$ & 35 & 40 & 12.0 & 12.0 & 1.40 & 1.40 & 0.24 & 0.22 & -0.03 & 0.97 & IS \\
\hline 2 & Weight & 35 & 40 & 56.5 & 54.7 & 5.32 & 5.57 & 0.89 & 0.88 & 1.42 & 0.15 & IS \\
\hline
\end{tabular}

On comparing the effect of therapies on objective parameters it was observed that there was insignificant difference between the therapies in hemoglobin and weight of the patients.

In Group A, $8.5 \%$ patients got mild relief, $17.14 \%$ got moderate relief and $68.57 \%$ patients got marked relief. In Group B, $7.5 \%$ patients got mild relief, $17.5 \%$ patients got moderate relief and $80 \%$ patients got marked relief. On comparison between the groups it was observed that in all the parameters the difference was statistically insignificant except in altered bowel movement where the difference was statistically mildly significant.

\section{Discussion:}

In today's era of lifestyle changes, improper food and dietary habits, the digestive system has suffered the most. Grahani roga is a disease where "Grahani" as a structure is unable to perform its normal function of holding on the uncooked food particles till they get digested. Grahani is a disease in which agni (digestive power) is at fault. So, to enhance the potency of agni, thereby reducing the formation of Ama Dosha, the trial drugs were selected.

In this study, $73.75 \%$ patients were males attributing to their unavoidable exposure to external environment along with food habits and drinking of contaminated water. Maximum incidence was observed in $3^{\text {rd }}$ followed by 2 nd decade of life. Young adults of these age groups are more exposed to unhygienic eating habits and mental stress. It was also observed that tea/ coffee intake group was affected more because tea/ coffee cause irritation in the gastrointestinal tract. Maximum patients had vata pitta prakriti which signifies that if such persons get indulged in vata and pitta aggravating factors, it may result in agni dushti as well as vitiation of samana vayu (more than patients with other prakriti) which are the main causes of Grahani roga. Both the groups showed statistically significant results in clinical symptoms i.e. altered bowel movements, thirst, anorexia, nausea, blackouts, pain in bones and joints, sour eructations, but the mean reduction in the symptoms of group B was more than group A. Better effect of group B were observed which may be due to better absorption of Takrarista and also because arishta is Deepana (appetizer) by nature.

\section{Mode of action of drugs:}

Musta (Cyperus rotundus) is pungent, bitter and astringent in taste, pungent in the post digestive effect and has cold potency. Acharya Charaka and Vagbhata has mentioned it as Dipaniya (appetizer), Pachaniya (digestant) and Sangrahi (anti-diarrhoeal). It is also well known for its A mapacaka property (digests ama). (6)

Musta has limited activity against different forms of infectious diarrhoea due to its selective activity against diarrheal pathogens, in the absence of a marked activity, this plant seems to have antidiarrheal action because of its action on some features like bacterial colonization, production of cholera toxin and action on labile toxin. (7)

Babbula (Acacia arabica) is astringent in taste, pungent in post digestive effect and has cold potency. It possesses astringent property which makes it very useful in bleeding disorders like bloody diarrhoea. It offers marked liver protection and has anti- oxidant activity. Anti- bacterial activity has also been reported with highest activity against Escherichia coli, Staphylococcus aureus and Salmonella typhi. (8)

Takrarista is an ayurvedic formulation and is indicated against haemorrhoids, worm infestation, loss of appetite, grahani and diarrhoea. Most of the drugs used in this compound are Laghu and Tikshna in guna and has Ushna potency and therefore has deepan and grahi property. Takra in Takrarista is a fermented product and refermentation of the same with some more salts and herbal drugs yields more stable product containing little amount of alcohol and dominant characters of acidic fermentation. (9) 
Lactic acid bacteria present in curd are reported for the anti- microbial activity due to the production of antibiotics like substances and peptides. A mla, harda, ajowan and maricha which are used in GI disorders, have also exhibited anti microbial activity. Piperin obtained from maricha is a bio- availability enhancer. So, the anti-bacterial activity of Takrarista may be ascribed to the presence of metabolites of lactic acid bacteria, antibacterial activity of herbal constituents and conversion products formed by microbial activity during fermentation. (10)

\section{Scope of future research:}

Larger number of sample size should be included to confirm our results and generalize the results to population outside this sample population.

\section{Conclusion:}

This is evident from both clinical and statistical improvement that the drugs Mustababbula churna and Takrarista are effective in the treatment of Grahani. The drug Mustababbool Churna is an anubhoot preparation and Takrarista described by Acharya Charaka in the management of Grahani Dosha, which was selected for study is an excellent combination of Deepana, Pachana drugs. Mustak exhibit the antidiarrheal action because of its action on some features like bacterial virulence viz., bacterial colonization, production of Cholera Toxin and action of Labile Toxin. Acacia arabica offers marked liver protection, and has anti- oxidant activity. Takrarista has anti-diarrhoeal, antihaemorrhoidal, anti-bacterial and anti-helmintic activity owing to the presence of metabolites of lactic acid bacteria, anti- bacterial activity of herbal constituents and conversion products formed by microbial activity during fermentation.

It can be concluded from the present study that Mustababbool churna is very effective in the management of Grahani but when used with Takrarista it was more effective and also improve the state of Agni.

\section{References:}

1) Agnivesh, Charak samhita by Pandit Kashinath Shastri \& Dr. Gorakhnath Chaturvedi, Grahani Chikitsa, Volume 2, Chapter 15, Verse-52. Varanasi. Chaukhambha Bharti Akadami. Reprint
2007, Page no. 461

2) Agnivesh, Charak samhita by Pandit Kashinath Shastri \& Dr. Gorakhnath Chaturvedi, Grahani Chikitsa, Volume 2, Chapter 15, Verse-121. Varanasi. Chaukhambha Bharti Akadami. Reprint 2007, Page no. 470

3) Agnivesh, Charak samhita by Pandit Kashinath Shastri \& Dr. Gorakhnath Chaturvedi, Grahani Chikitsa, Volume 2, Chapter 15, Verse-53, 54. Varanasi. Chaukhambha Bharti Akadami. Reprint 2007, Page no. 461

4) Govt. of India, The Ayurvedic Pharmacopoeia of India, The Controller of Publications Civil Lines, Delhi. Dept. of AYUSH. Part-2. Volume-2. First edition. 2008. Page no. 79

5) Govt. of India, The Ayurvedic Formulary of India, The controller of Publications Civil Lines, Delhi. Dept. of AYUSH. Part-3. First edition.

6) Agnivesh, Charak samhita by Pandit Kashinath Shastri \& Dr. Gorakhnath Chaturvedi, Grahani Chikitsa, Volume 1, Chapter 25, Verse-40. Varanasi. Chaukhambha Bharti Akadami. Reprint 2008, Page no. 469

7) N Singh, B. R. Pandey, P Verma, Phytopharmacotherapeutics of Cyperus rotundus Linn. (Motha): An overview- Indian Journal of National Products and Resources, Vol. 3 (4), December 2012, pp 467-476

8) M.U.Z.N. Farzana, I.AI Tharique, Arshiya Sultana, A review of ethnomedicine, phytochemical and pharmacological activities of Acacia nilotica (linn) wild, Institute of Indigenous Medicine, Sri Lanka, Journal of Pharmacognosy and Phytochemistry, 2004, Page no. 84

9) Krishnamurthy M. S, Dwivedi Laxmikanth, Rao Ravi S, A critical study on Takrarista, International Research Journal of Pharmacy, 2011, Page no. 159

10) Sandeep Bhardwaj, Girish S Achliya, In vitro antibacterial activity of Takrarishta- An Ayurvedic formulation, Indian Journal of Traditional Knowledge , Vol. 4(3), July 2005, Page no. 325-328 